Judit Siket ${ }^{*}$

\title{
CENTRALISATION - DECENTRALISATION - DECONCENTRATION IN THE CONTEXT OF LOCAL PUBLIC SERVICE PROVISION
}

\section{Centralization of Local Public Services: An Attempt to Balance Disintegration Effects}

Traditionally, three principal areas of local self-government autonomy could be distinguished, especially in the European continental local self-government model. These elements are being shaped by the autonomy of carrying out local public affairs, financial autonomy, and freedom to establish local bodies of self-government and to recruit its personnel. Effective management of local public affairs needs the emergence of subsidiarity as a given state organizational principle, and to be guaranteed sufficient sources to performance of local self-governments' responsibilities. The general competence theory of local public service provision presupposes the availability of adequate resources, and the decision-making ability of local governments to choose the form of task delivery, to conduct contract award procedures and to exercise the control functions according to their compliance and the execution. Local self-governments have the right and obligation to provide local public services, and are responsible for developing public tasks required by law.

Judit Siket - PhD, Senior Lecturer at the University of Szeged, Department of Administrative Law, Faculty of Law and Political Sciences, Hungary. 
The scope of public tasks performed by local self-governments changes from time to time and also shows a diverse picture state by state. The state decentralization system could be described, from a certain point of view, as the manifestation of public service provision by local self-governments.

The study is an attempt to overview the emergence of decentralization, especially financial decentralization issues in the field of local public service provision. First of all, the analysis implicates a dogmatic fiscal and functional approach of local administrative autonomy; secondly, in the scope of local public services outlines appreciable tendencies of changing processes; and finally, presents the centralization process of Hungarian local public services, as an attempt serves the balancing of disintegration effects.

\section{Financial decentralization - fiscal federalism}

The term of fiscal federalism was introduced by Richard Musgrave, and in general term it deals with the division of governmental functions and financial relations among levels of government. The main purpose of this chapter is to demonstrate the theoretical background of fiscal federalism, ${ }^{1}$ in other words, financial decentralization and its connection to unique features of local public service provision.

1 The concept of fiscal federalism is used in various senses in the public finance literature. According to one possible interpretation, fiscal policy is an area of economic policy its object being to influence public revenues and expenditures. On reading the general terms of federalism, fiscal federalism can be interpreted - inter alia - in the federal state system, in relations of the European Union and its Member States, additionally in the field of performance of public functions in a decentralized state system. See: r.A. Musgrave, The Theory of Public Finance, McGraw-Hill, New-York 1959; cf.: A. Szalai, Fiskális föderalizmus, Közgazdasági Szemle, Vol. XLIX, May 2002, p. 425; W.E. Oates, Fiscal Federalism, New York: Harcourt Brave Jovanovich 1972, p. 150; J. Cullis, P. Jones, Közpénzügyek és közösségi döntések, Aula 2003, p. 479; T. Ter-Minassian, Fiscal Federalism. Theory and Practice, International Monetary Fund, 1997; P.M. Boothe, Reforming Fiscal Federalism for Global Competition, University of Alberta Press, 1996; J.E. Stiglitz, A kormányzati szektor gazdaságtana, KJK KERSZÖV Budapest, 2000; T.M. Horváth, G. Péteri, Vécsei, Pál: A helyi forrásszabályozási rendszer magyarországi példája, 1990-2012, Közgazdasági Szemle, Vol. LXI, February 2014, 
Financial decentralization is a form of manifestation of financial autonomy. When examining the substantial relationships between responsibilities of local self-governments and management, a short mention on the main features of fiscal federalism has to be made. The interpretation of federalism - seen in these terms - includes those constitutional provisions, according to which there is a division of tasks and powers between different levels of government. The power-sharing method determines the state functional and economic competences entrusted to its decentralized organizations. The context between centralization and decentralization determinates basically the supply of public services at the central government level and the territorial or local level.

The phenomenon of fiscal federalism, from a certain point of view, could be identified with decentralization. "Fiscal federalism (decentralization) is a public spending system, where the raising power of revenues and the determination of expenditure programs are shared between the different levels of governments." With regard to the financial decentralization, Wallace E. Oates adopted the position as follows: "Central government could deal with problems of allocation, and to ensure public services is responsibility of decentralized levels." ${ }^{3}$ Relationship between centralization and decentralization is determined basically at the level of performance of public services: whether the central, governmental or territorial, local level is appropriate for public service delivery for citizens in specific cases. Public finance literature - following Musgrave - started from the three main functions of government, like allocation, redistribution and stability, in determining the responsibility for public service supply. ${ }^{4}$ The allocation function may be entirely decentralized and, it should be noted, that the emergence of this func-

pp. 121-147; G. Csürös, Uniós pénzügyek. Az európai integráció fejlödésének pénzügyi jogi vizsgálata, HVG-ORAC, Budapest 2015, pp. 38-42; G. Garzarelli, Old and New Theories of Fiscal Federalism, Organizational Design Problems, and Tiebout, 2005; https://ideas. repec.org/p/wpa/wuwppe/0509009.html.

${ }^{2}$ K. Botos, A. Schlett, Államháztartástan, Szent István Társulat az Apostoli Szentszék Könyvkiadója, Budapest, 2010, $2^{\text {nd }}$ updated edition, p. 89.

3 W.E. Oates, Fiscal Federalism..., p. 150. Cf. J. Cullis, P. Jones, Közpénzügyek és közösségi..., p. 479.

${ }^{4}$ R.A. Musgrave, The Theory of Public Finance...; A. Szalai, Fiskális föderalizmus..., p. 425 . 
tion could be influenced negatively by different factors. ${ }^{5}$ The stability function and redistribution could be performed more efficiently at the central government level, but the allocation at the local government level. Nevertheless, these functions could not be completely separated at different levels, as overlaps could arise. ${ }^{6}$ This dilemma leads to the determination of "optimal self-government", supposed to mean that there are the borders of economies of scale in the area of local public service delivery. ${ }^{7}$ The aspects of economies of scale were given particular attention in the Scandinavian countries, in the development procedure of the optimal municipal system, in the 1980s. States showing the specialties of the Scandinavian (North) local self-government system model are characterized by a wide range of powers and the larger scope of financial and management autonomy. By contrast, Latin (Southern) model represents a lower degree of autonomy, both in terms of competence and management.

Where the state functions are decentralized, it should be considered, that certain organizations of local self-government system might be under competition conditions at the market of public service supply, furthermore, a competing position may arise when obtaining different resources. Beyond the problem of economies of scale in the field of local self-governance, another issue could be identified, i.e. the phenomenon called "feet-voting", ${ }^{8}$ in the scientific literature known as Tiebout model.

Beside a much easier access to information at the local level about the needs of citizens, a key argument for decentralization is the accountability, control effectiveness. Voters of the geographic, territorial or local units could evaluate in the most appropriate way activities of local

${ }^{5}$ A. Szalai identified such a problem the informational difficulties. The argument for the decentralization is that the lower level organizations can bring information much easier to the needs of population, while gathering information at the central level can cause significant transaction cost. In contrast, however, centralization can be strengthened by what is called overflow effect, and economies; cf. A. Szalai, Fiskális föderalizmus..., pp. 425-426.

${ }^{6}$ K. Botos, A. Schlett, Államháztartástan..., p. 89.

7 A. Szalai, Fiskális föderalizmus..., p. 426.

${ }^{8}$ Citizens choose a place of residence on the basis of the local taxes and the quality of local service provision. See J.E. Stiglitz, A kormányzati szektor..., pp. 645-646. 
self-government bodies, so during the elections members of representative bodies could be accountable. Regarding this subject, however, the awareness of voters, following of interests, rational voting behaviour are also factors in community decision-making. A voter is a dominant factor of the community decision-making mechanism, in accordance with the theory of rational voters drawn up by Anthony Downs. The main question of the hypothesis is what benefit the voter may expect from participating in the election process. "When considering whether vote or not, the individual estimates how much better it is, if his vote results in the desired victorious result." Regarding the awareness of voters, the cost of gathering information is to be taken into account, because it is not certain that the voters are taking the costs, therefore lack of awareness of rational voters influences the election result. ${ }^{9}$ In the context of voters participating in community decision-making, the theory of fiscal illusion has been formulated by which voters are not able to estimate realistically public expenditures and the benefits resulting from these expenditures. ${ }^{10}$ Concerning the issue of decentralization, from the point of view of governmental functions, the impact of the stabilization function is worth mentioning. ${ }^{11}$ The stabilization function is to be considered only as a state function, the territorial, local decentralized organizations will not be able to react effectively to economic development processes and to balance the potential crisis situation. The public service supply and economic policies of territorial and local self-government must be consistent with macroeconomic objectives. Therefore, territorial and local self-governments, established as a result of decentralization, have to take into account in their functioning national economic goals. ${ }^{12}$

Examining the aspect of financial decentralization, the revenue sources of territorial and local decentralized organs deserve particu-

9 A. Downs, An Economic Theory of Democracy, New York: Harper \& Row. Cf. J. Cullis, P. Jones, Közpénzügyek és közösségi..., p. 109.

${ }^{10}$ J. Cullis, P. Jones, Közpénzügyek és közösségi..., pp. 134-135; A. Szalai, Fiskális föderalizmus..., p. 429.

${ }^{11}$ For example, in the Hungarian domestic context, the indebtedness of local self-governments, particularly in the second half of the 2000s, had a serious negative impact on the lack of public finances.

12 A. Szalai, Fiskális föderalizmus..., p. 430. 
lar attention. As previously indicated, it is obvious that only local revenues could not be sufficient resources for local and territorial self-governments to exercise public authority and to provide public services. The budget of local self-governments is largely determined by resources transferred by the state.

One of the most important questions is what kind of taxation power ${ }^{13}$ is provided at the local and territorial level and how the decentralized body could benefit from the state revenue obtained in its territory. As a result of decentralization, increasing attention is paid to establishment of such a taxation and financial transfer system which is capable of creating consistency between local government tasks and revenues. ${ }^{14}$ Resources available for territorial and local governments, transferred by the state can serve a variety of state objectives. To reach these aims, the public service could be maintained only at the level considered necessary by the state, eliminating the imbalance resulted from the different ability of territorial and local self-government to generate or to gather revenues. There are several types of resources transferred by the state government, which the decentralized organization can get unconditionally and finance particular tasks, or the state can set any additional conditions. ${ }^{15}$ Unconditional grant, general grant, conditional non-matching grant, and matching grant can be distinguished as categories of state transfers. This categorization can be interpreted in the field of budget management of local self-governments in Hungary as well, but it should be mentioned that the unconditional grants form was abolished from the financing system, and the normative financing has been replaced by task financing since 2012 .

The Second Generation Theory of fiscal federalism is based on widerange research. One of the most important finding is that decentral-

${ }^{13}$ Principles of decentralized taxation and allocation of revenues are traditionally defined by Musgrave. For states with multilevel governance, the most important question of decentralized taxation is who should tax where and what the subject of taxation is ("Who should tax, where and what?", R.A. Musgrave, 1983); R.M. Bird, Rethinking Subnational Taxes: A New Look at Tax Assignment, IMF Working Paper 1999, p. 4: http://www.imf.org/external/pubs/ft/wp/1999/wp99165.pdf.

14 IMF Working Paper, 1999, pp. 4-5.

15 A. Szalai, Fiskális föderalizmus..., pp. 434-435. 
ization has ability to prevent the concentration of power, to improve the credibility of the government, and to enable population to better express their needs to government. ${ }^{16} \mathrm{New}$ interpretation possibilities of fiscal federalism have also emerged, and in addition to the national frameworks, states and governmental dimensions may also be subject of examination. ${ }^{17}$ Furthermore, it should be noted that the Council of Europe is strongly committed to examine the financing of local self-governments as a tool of modernization process of public service delivery.

\section{The scope of public service supply}

The ability of local governments is to govern responses to different challenges and opportunities by involving in institutional and policy-actor networks. Local governance is based on a new perception of public management that tries to introduce concepts like effective efficiency, capacity and autonomy, furthermore, the expansion of legitimacy, transparency, democracy and participation, entailing that local self-governments interconnect with strategic actors for a collective decision-making and conflict resolution in accordance with a system of rules and procedures. ${ }^{18}$ Local governance comprises a set of institutions, mechanisms and processes, through which citizens and their groups can articulate their interests and needs, mediate their differences and exercise their rights and obligations at the local level. The building blocks of good local governance are many: citizen participation, partnerships among key actors at the local level, capacity of local actors across all sectors, multiple flows of information, institutions of accountability, and a pro-poor orientation. ${ }^{19}$

16 P. Halmos, Önkormányzatok pénzügyi és vagyoni kockázatai Magyarországon, PhD dissertation, p. 26: http://doktori.bibl.u-szeged.hu/855/1/Disszertacio_HP.pdf.

${ }^{17}$ G. Csűrös, Uniós pénzügyek. Az európai integráció fejlődésének pénzügyi jogi vizsgálata, HVG-ORAC Lap és Könyvkiadó Kft., Budapest 2015, pp. 38-42.

18 UCLG, Decentralisation and Local Self-Government Committee, http://www. uclg-decentralisation.org/en/committee/glossary.

19 UNPD, 2004, Decentralised Governance for Development: A Combined Practice Note on Decentralisation, Local Governance and Urban/Rural Development, http://www. undp.org/content/dam/aplaws/publication/en/publications/democratic-governance/ 
From this point of view, development of public policy, decision-making and enforcement procedures, in which local self-governments (bodies elected according to the principle of decentralization) encourage equal participation of all relevant territorial actors (state, civil society, citizens, businesses), strengthens accountability for citizens and responsibility towards social expectations in the public interest, preserving public interest objectives. ${ }^{20}$

It is established that there might be many contradictions regarding regulatory and administrative issues in local public affairs if in unilaterally and exclusively delegated powers the principle of decentralization prevails exclusively. Centralization and decentralization could not be the only decisive organizational principles for the establishment and functioning of local and territorial self-governments, in the form of local government segment of territorial governance. It is reasonable to consider case-by-case the optimal model for both functional and other political, administrative, and financial components of the competencies when establishing individual public service responsibilities.

In recent years, a paradigm shift could be perceived in the area of provision of public services. How can the main features of these changes be described? These include the following phenomena: (1) the dominance of New Public Management has declined; (2) the decentralized model of sharing public service delivery's power and responsibilities has changed; (3) the scope of public service provision has been rearranged. ${ }^{21}$

dg-publications-for-website/decentralised-governance-for-development-a-combined-practice-note-on-decentralisation-local-governance-and-urban-rural-development/ DLGUD_PN_English.pdf.

20 The European Charter on development cooperation in support of local governance, 2008, http://www.cittametropolitana.mi.it/export/sites/default/relazioni_internazionali/ doc/1182_european_development_cooperation_charter_in_support_of_local_governance.pdf.

${ }^{21}$ I. Pálné Kovács, I. Finta (eds.), A helyi közszolgáltatások helyzete és fejlesztésük javasolt irányai, 2014, http://arop.rkk.hu:8080/Dokumentumok/18_zarotanulmany.pdf, p. 11. 
Public service delivery serves meeting the common needs of society. These responsibilities require common organizational activities. ${ }^{22} \mathrm{By}$ another approach " $\mathrm{T}]$ he most important public services are manifested in Fundamental Laws of certain States as fundamental rights. Services classified as public services by the State law, by application of certain procedural rules, are supplied, financed or regulated by the State." ${ }^{23}$

Furthermore, it can also be concluded that there are several organizational and operational systems of public service delivery, like the Anglo-Saxon, French, and German models. The framework of the study is too limited to present the most important features describing these models. Still, it is inevitable to mention the constantly changing and shaping public procurement and public service delivery policy of the European Union.

The Amsterdam Treaty of 1997 determined the application of a liberalization policy in the field of public service delivery. After this period, the government and political factors have risen to the forefront, affected by the public service policy. The two most important measures prevailing typically could be highlighted as follows: allowing state grants, and the possibility of exemption from public procurement rules. These features would be referred in relation to Hungarian public service regulations, as well. Reference should also be made to services of general economic interest. The general rules on these services are provided for in the Treaty on the Functioning of the European Union. ${ }^{24}$

${ }^{22}$ T.M. Horváth, Közmenedzsment, Dialóg Campus Kiadó, Budapest-Pécs 2005, p. 281.

${ }^{23}$ I. Hoffman, Önkormányzati közszolgáltatások szervezése és igazgatása, ELTE Eötvös Kiadó, 2009, p. 41.

${ }^{24}$ Article 106. 2. Undertakings entrusted with the operation of services of general economic interest or having the character of a revenue-producing monopoly shall be subject to the rules contained in the Treaties, in particular to the rules on competition, in so far as the application of such rules does not obstruct the performance, in law or in fact, of the particular tasks assigned to them. The development of trade must not be affected to such an extent as would be contrary to the interests of the Union. (OJ C 326/01, 26.10.2012). 


\section{Delivery of local public services in Hungary}

Restructuring of the local self-government system in Hungary may be interpreted as a centralization process of public tasks within the framework of the decentralized structure. The new governing system resulted in a high degree of centralization in the field of public responsibilities' implementation, and was closely linked with the financial consolidation process of local self-governments in the years 2011-2012. Expert studies ${ }^{25}$ regarding exchange of financial and budgetary conditions evidenced at the same time that local self-governments are less able to influence public service supply in case of socialized services. The legislator ensures and regulates possible means of influencing for local self-governments in sectoral legislation, but it can be doubted whether the quality of the services can be affected by them.

As a result of the European Union changing public service policy, core regulation has been fundamentally changed also in Hungary. Directive 2004/17/EC on rules applicable to procurement by entities operating in the water, energy, transport and postal services sectors until $2016,{ }^{26}$ has already resulted in an exemption from compulsory competitive tendering. The series of measures aimed at restoring liberalization and privatization started to be implemented already in 2011-2012. The Act on National Assets ${ }^{27}$ has further strengthened the state ownership function. ${ }^{28}$

To gain a better understanding of relating financial decentralization and public service provision, however, first of all, it is necessary to

${ }^{25}$ K. Szamel, A magyar helyi önkormányzati rendszer átalakitása európai kontextusban. Új Magyar Közigazgatás, May 2012, p. 28.

${ }^{26}$ Directive 2004/17/EC of the European Parliament and of the Council of 31 March 2004 on the coordination of the procedures for awarding public procurement in the water, energy, transport and postal services sectors, http://eur-lex.europa.eu/legalcontent/EN/TXT/HTML/?uri=LEGISSUM:122010\&from=HU; implemented in Hungary by the Act XXIX of 2005.

27 Act CXCVII of 2011 on National Assets.

${ }_{28}$ T.M. Horváth, Európa Csendes fordulata, [in:] T.M. Horváth, Magasfeszültség. Városi szolgáltatások, Dialóg Campus Kiadó, Budapest 2015, pp. 203-204. 
explore the situation before the changing of government in 2010, on which the centralization process is based.

After the political transition a liberal, democratically elected local self-government system was established in Hungary. The system was based on the concept of the general competences. It means that all public affairs can be carried out by the local authority. In 1990, a two-tiered local self-government system was established, consisting of municipalities and county governments. There was no hierarchical relationship between equal local self-governments in counties and settlements. Their responsibilities and functions were delimited. The most important feature of the local government system was that every municipality had a local self-government authority in its own right. Every settlement had same rights and responsibilities, regardless of the population, economic power and opportunities at the beginning of the 1990s. The Self-Government Act of $1990^{29}$ adopted the concept of local self-government with a broad scope of responsibility. Legislation might refer management of local public affairs to another organization only exceptionally. The local authorities might voluntary undertake any local public affair not referred by law to the competence of another body. They might independently determine what voluntary function to perform and to what extent and how, in accordance with local needs and possibilities. The local authorities also enjoyed autonomy as to the manner in which they performed the obligatory tasks. According to the provisions of the Constitution and the Local Government Act, the main compulsory responsibilities in the field of public services were as follows: primary education, basic social services, basic health care, safe drinking water, public cemeteries, maintenance of local public roads and public areas, the provision of city cleaning, public lighting. Mandatory delivery of services may also be prescribed by other regulations. In relation to provision of municipal services, self-governments are authorized to exercise local public power.

However, it could be stated that the negative impact arising from the exaggerated decentralization was clearly experienced by the mid-

29 Act LXV of 1990 on Local Self-Governments. 
1990s. The system proved simultaneously the inadequacy of resources needed to perform the obligatory local self-government tasks and the unused capacities. All this coupled with the economic regulation system that provided considerable autonomy for local self-governments, which could not prevent the indebtedness process. The primary cause of the unavoidable changes following 2010 was the indebtedness of local self-governments; especially the county governments were affected by this process. The indebtedness of local governments accelerated after the municipal elections in 2006, which was an atypical debt-inducing process by András Vígvári. On the one hand, it functioned as a cash reserve for a shorter period of time and was not directly used, but for arbitrary operations, and on the other hand, the role of banks in the validation of short-term business interests prevailed. ${ }^{30}$

The reform of local financial system was not the subject of the Fundamental Law; the essential provisions relating to the management of local self-government are detailed in the New Local Government Act, ${ }^{31}$ in the Act on the Economic Stabilization of Hungary, ${ }^{32}$ and in the Act on State Finance. ${ }^{33}$ The debt consolidation process was regulated in the Acts on annual state budgets. It is relevant to note that debt consolidation process has taken place in several phases of the local government sector. The first step was the consolidation of the county self-governments, followed by the consolidation of the settlements, parallel with the socialization of local authorities' responsibilities. The debt consolidation of two-thirds of the Hungarian settlements completed, involving on the whole of almost 2,000 local governments. The performance of the debt was undertaken by the state. In parallel with the debt-consolidation process, local self-governments functions were socialized, such as the hospital and specialised care, public education, social and children welfare system, as regards the provision of services in the institutions. Most of the remaining tasks of municipalities are self-government tasks in the classical sense (administrative tasks,

30 A. Vígvári, Atipikus önkormányzati eladósodás Magyarországon, Közgazdasági Szemle, Vol. LVI, July-August 2009, p. 710.

31 Act CLXXXIX of 2011 on Local Self-Governments of Hungary.

${ }^{32}$ Act CLXCIV of 2011 on the Economic Stabilization of Hungary.

33 Act CXCV on State Financing. 
settlement operations, street lighting, local taxes, etc.). Revenue from local taxes remains in the hands of local authorities entirely as own resources, to contribute the national resources.

Functionality of local self-governments' responsibilities basically concerned the restructuring process. The expansion of the state in the provision of local public services has had a negative effect on the emergence of the principle of subsidiarity in the management of local public affairs. Decentralization is of vital importance to the volume and quality of local public services; it is the segment that is most visible for local communities. A crucial element of municipal autonomy is what tasks are performed through the local self-government system. Functional autonomy could be achieved when "responsibilities of local self-governments establish the objective of constitutionally defended independence; hence they have independence as to fulfilment of local tasks." ${ }^{34}$ Local self-governments are primarily responsible for the provision of public services to the population of settlements. The autonomy elements are worth considering from the point of view of local self-governments' sufficient authority to perform the obligatory tasks in the field of organizing provision of certain public services.

After the change of government in 2010, local self-government responsibilities were transferred to the scope of the state tasks, and this process may lead to the abolition of the content of local self-governments' public affairs. Furthermore, it can also be seen that the state's supply of public tasks has not entailed the necessity of rationalization, the need for economies of scale and emergence of higher level public service quality. All along, performing of public tasks is characterized by strict regulation, the provision of service requirements, strengthening the control and, on the part of local self-governments, there is a decreasing margin for local discretion. It should be highlighted that no structural reform has been achieved. Beyond the negative effects on political legitimization, the lack of local democracy and social cohesion, the professional, operational tasks and development policy are separated.

${ }^{34}$ A. Patyi, A. Varga Zs., Általános Közigazgatási Jog, Egyetemi jegyzet, Mandamus Publishing, 2008, p. 316. 


\section{Closing remarks}

Fundamental changes in the Hungarian local self-government system after 2010 could be considered a part of a marked centralization process. It consisted of a hardly imposable under the general philosophy of multi-level governance, coordinated, multilevel and multi-player, complex decision-making mechanism. The procedure of recentralization brought about substantial changes in provision of public services that affected the essential part of local public affairs. The theoretical basis of general competence theory which characterized the fulfilment of responsibilities of local self-governments has been weakened, and the principles of decentralization and subsidiarity prevail to a limited extent.

The opinion that excessive decentralization could distort the operability and could jeopardize high-level, territorially balanced provision of public services should also be voiced. The decentralization and subsidiarity are the basis of local self-governance of a modern, democratic state, but the delegation of local responsibilities shall be conducted in accordance with the professional requirements of the division of power between the state and local governments, with economic performance and the needs of local public services at the same level.

The real question is whether it is possible to provide all public services as close as possible to consumers. Responsibilities of local self-governments have still not been aligned to the territorial special features; and the allocation function of financial decentralization could not effectively prevail. The central government has to determine the basic conditions of public service delivery, inter alia, the optimum size of organizations, and furthermore the form of coordination which leads to provide the highest level, well-balanced service delivery in the public sector. The intervention of central government, even if it is only by coordination, could be considered a centralization process.

The nationalization process cannot be designed to be complete, because there is no legal objection to remove of local self-government responsibilities and, consequently, to withdraw the local self-government assets as well. 